\title{
Zero Humanity
}

\section{The Reality of Current US Immigration Policy toward Central American Refugee Children and Their Families}

\author{
Jacqueline Bhabha
}

\section{INTRODUCTION}

Many months have passed since the Trump administration's initial ruthless separation of more than 4,300 babies and children from their parents at the United States' southern border. ${ }^{1}$ Since that time, partly under the guise of public health concerns prompted by the COVID-19 pandemic, the administration has continued to impose draconian rights-violative policies on migrant children - not just family separation but summary deportation. ${ }^{2}$ Irrespective of changing circumstances, the underlying administrative philosophy - that deterrence is the solution to humanitarian emergencies that drive forced migration - remains in place. This philosophy subordinates American constitutional values and international obligations to non-citizens to the instrumental goal of reducing access to US soil for people fleeing life-threatening violence, however strong their claim to protection.

By doggedly implementing policies that block, detain, deport, and humiliate humanitarian migrants, the United States is participating in what the authors of Chapter 6 in this volume have usefully termed "a system of global apartheid." Moreover, just as South African apartheid encouraged the development of a movement to overthrow racist state oppression, local and underground at first but global over time, so is global apartheid encouraging the development of alternatives to racist migration exclusion. Smuggling networks, caravans, global migration compacts, trafficking rings, Facebook-mediated migration itineraries, and heroic

1 "Attorney General Announces Zero-Tolerance Policy for Criminal Illegal Entry," United States Department of Justice, Office of Public Affairs, April 6, 2018, www.justice.gov/opa/pr/ attorney-general-announces-zero-tolerance-policy-criminal-illegal-entry.

2 "Family Separation Policy Continues Two Years after Trump Administration Claims It Ended," Southern Poverty Law Center, www.splcenter.org/news/2020/06/18/family-separationpolicy-continues-two-years-after-trump-administration-claims-it-ended; C. Dickerson, "10 Years Old, Tearful and Confused after a Sudden Deportation," NY Times, May 21, 2020, www .nytimes.com/2020/05/20/us/coronavirus-migrant-children-unaccompanied-minors.html. 
individual voyages are just some of the current modalities. Others will develop over time, as vigorous and ambitious populations, intent on saving their lives and sharing the all-too-visible bounty generated by a global capitalist commons, refuse enduring and oppressive sequestration. But, as it was in South Africa, the process is protracted and arduous, and hugely costly in terms of human lives and suffering. As they tried to access safety, nearly 19,000 people drowned in the Mediterranean from 2014-2019, ${ }^{3}$ 2,243 perished in the deserts between the United States and Mexico, and tens of thousands faced excruciating detention conditions in rogue jails in Libya. ${ }^{4}$

The US-bound exodus of Central American children and their families, from some of the poorest and most violent countries in the world, and the US government's responses provide a case study of global apartheid in action. In what follows, after outlining the United States' key legal obligations toward non-citizens, I will track some of the policies deployed by the Trump administration to block or otherwise deter the entry of humanitarian migrant children and families. I will suggest that these policies are not only inhumane and in violation of binding legal obligations, but also futile. I will conclude by outlining what I consider more rightsrespecting and effective alternatives.

\section{The United States' International and Constitutional Obligations to Non-citizens}

The United States is an outlier when it comes to ratification of international treaties. No better illustration exists than the situation regarding its stance on children's rights. Alone among member states of the United Nations, the United States has not ratified the 1989 UN Convention on the Rights of the Child (CRC), the cardinal international human rights treaty consolidating the principles that apply to children. ${ }^{5}$ Central among these principles is the prohibition on discrimination and the obligation to make the child's best interests a primary consideration in actions and policies affecting them. Because these principles have been consistently applied by an overwhelming majority of countries for well over half a century, they may be considered customary international law, and therefore cannot be disregarded by the US government.

In practice, failure to ratify the CRC has reduced the leverage of international institutions such as the Committee on the Rights of the Child and UNICEF, and US-based child rights advocates, to press for enforcement of fundamental rights for

3 "Migrant Deaths and Disappearances," Missing Migrants Project: International Organization on Migration. November 8, 2019, https://migrationdataportal.org/themes/migrant-deaths-anddisappearances.

4 "Libya Immigration Detention," Global Detention Project, August 18, 2018, www.global detentionproject.org/countries/africa/libya\#_ftn4.

5 Convention on the Rights of the Child, November 20, 1989, 1577 U.N.T.S. 3, www.refworld .org/docid/3ae6b38fo.html. 
migrant children. The egregious 2018 family separation border policy would doubtless have elicited more vigorous international protest had the UN Committee on the Rights of the Child been afforded oversight.

The United States has, however, ratified other international treaties that generate powerful obligations towards persons within its jurisdiction irrespective of their citizenship status. They include the 1966 International Covenant on Civil and Political Rights (ICCPR), ${ }^{6}$ the ${ }^{1951}$ Convention Relating to the Status of Refugees, ${ }^{7}$ and the 1984 Convention against Torture and other Cruel, Inhuman or Degrading Treatment or Punishment. ${ }^{8}$ Treaties are considered the supreme law of the land under the US Constitution, so government actions have to be consistent with provisions in ratified treaties. 9 The implications of these obligations in relation to Central American children seeking protection in the United States from violence at home are multiple. One is the obligation not to subject children to arbitrary detention, whether in an immigration or any other context. Prolonged incarceration of children not charged with any criminal wrongdoing, with or without parents, violates this prohibition. Indeed, the UN High Commissioner for Refugees (UNHCR), the international agency charged with overseeing implementation of the Refugee Convention and the protection of refugees and asylum seekers, has explicitly held that "children should not be detained for immigration related purposes, irrespective of their legal/migratory status or that of their parents, and detention is never in their best interests." ${ }^{\circ}$ The Human Rights Committee, the treaty body that oversees implementation of the ICCPR, addressed the issue of detention of a child and parent seeking asylum specifically in a case it adjudicated. It explained that, as a general rule, detention "should not continue beyond the period for which the State party can provide appropriate justification." Because Australia, the country in question, failed to show that detention was the least restrictive strategy available for achieving its intended objective, it had violated its obligations. ${ }^{11}$

Another treaty obligation binding on the United States is the prohibition on subjecting asylum seekers, including children, to punitive treatment. ${ }^{12}$ Separating children from their parents clearly falls afoul of this prohibition, as does forcing

6 International Covenant on Civil and Political Rights, December 16, 1966, 999 U.N.T.S. 171, www.refworld.org/docid/3ae6bzaao.html.

7 UN Convention Relating to the Status of Refugees, July 28, 1951, 189 U.N.T.S. 137, www .refworld.org/docid/3beorb964.html.

8 Convention Against Torture and Other Cruel, Inhuman or Degrading Treatment or Punishment, December 10, 1984, 1465 U.N.T.S. 85, www.refworld.org/docid/3ae6bza94.html.

9 U.S. Constitution, art., VI, cl. 2.

10 United Nations High Commissioner for Refugees, UNHCR Position Regarding the Detention of Refugee and Migrant Children in the Migration Context, January 2, 2017, www.refworld.org/ docid/5885c2434.html.

${ }^{11}$ Baban v. Australia, United Nations Human Rights Committee, 7.2 U.N. Doc. CCPR/C/78/ $\mathrm{D} / 1014 / 2001$ (2003).

12 Convention Relating to the Status of Refugees, July 28, 1951, 189 U.N.T.S. 137, www.refworld . org/docid/3beorb964.html, art. 31 . 
child asylum seekers to await their asylum hearings in places, such as the Mexico borderland, known to be crime and violence infested. More generally, under Article 24 of the ICCPR, the United States is obliged to provide children with special "measures of protection." From this one can infer that official policies targeting children in the United States, whatever their citizenship or immigration status, need, at a minimum, to protect their health, well-being, and development. ${ }^{13}$ Policies that subject children to unsanitary conditions, traumatic experiences, or situations where essential health care is unavailable violate this fundamental obligation.

\section{Family Separation}

The welcome U-turn on the blanket Trump administration family separation policy, which ripped all children away from parents entering the country without prior authorization, came fairly promptly. On June 20, 2018, two months after the presidential order that legitimized the policy, the government was forced to neutralize it. Family separation on that scale only worked as long as it was a closely guarded secret. ${ }^{14}$ Once photos of toddlers ripped from distraught parents, internment camps with children in cages, images of young children bottle feeding unrelated infants, and tapes of babies wailing while their jailers sardonically commented on the "orchestra" they were holding became public, the administration faced a watershed moment, even against the backdrop of its increasingly inhumane border control policies. ${ }^{15}$

The bipartisan storm of protest that erupted branded the government's version of migrant deterrence as un-American. And indeed, the widely circulated images evoked the darkest days of American history - family separation under slavery, abduction of Native American children from their families, internment without trial of Japanese Americans wrongly considered enemy aliens. The images also triggered alarming expert pronouncements about the devastating, and likely longterm, impact of the traumatic separation on the mental and emotional health of the affected children. Scholars of early childhood development characterized the experiences willfully imposed on the separated children as "toxic stress," to affect neural pathways in the brain in young children and to lead to grave risks

13 ICCPR, art. 24.

${ }^{14}$ A modified version of family separation, exacerbated by the COVID-19 pandemic, continues to this day.

15 "Kirstjen Nielsen Addresses Families Separation at the Border: Full Transcript," New York Times, June 18, 2018, www.nytimes.com/2018/o6/18/us/politics/dhs-kirstjen-nielsen-families-sep arated-border-transcript.html; G. Thompson, "Listen to Children Who've Just Been Separated from Their Parents at the Border," ProPublica, June 18, 2018, www.propublica.org/article/ children-separated-from-parents-border-patrol-cbp-trump-immigration-policy.

${ }^{16}$ J. P. Shonkoff et al., "The Lifelong Effects of Early Childhood Adversity and Toxic Stress" (2012) 129(1) Pediatrics e232-e246. 
such as emotional instability, high anxiety, suicidal ideation, and prolonged depression. Experts pointed out that the terror of separation from a parent and removal to an unfamiliar, punitive location for an indefinite time, without explanation or family contact, could cause life-long damage. ${ }^{17}$ Predictably, accounts of serious mental distress ensued. ${ }^{18}$

Though the president has been forced to change course on family separation itself, it is not clear that his administrators will be able to rectify the immense harm done anytime soon. The instructions they are supposed to abide by are clear. On June 27, 2018, in a case brought by the American Civil Liberties Union, a district court judge in San Diego decided that family separation was unconstitutional, that separated children should be promptly reunified with their parents (within fourteen days for those under five, within thirty days for older children), that parents not yet in contact with their separated children should be provided with telephonic contact within ten days, and that no parents should be deported without their consent prior to reunification with their separated children. ${ }^{19}$

However, government officials were unable to comply with the court order. Astoundingly, no clear or centralized tracking system had been put in place to document and register each child taken from their parent into federal custody, no alien registration or other identifying number was given to parents to enable them to trace their children's whereabouts, no cross-referencing system linked separated parent and child, and no liaison with consular authorities was established to ensure diplomatic contact between vulnerable foreign nationals and their national representatives. As the San Diego judge hearing the ACLU case, Judge Dana M. Sabraw, bitingly commented: "The unfortunate reality is that under the present system, migrant children are not accounted for with the same efficiency and accuracy as property." ${ }^{20}$ As a result the agonizing separation of parents and children continued for weeks, in some cases months. Even worse, some families seem to have been permanently separated as already deported parents, without access to lawyers or other advisers, encounter unsurmountable difficulties reuniting with children for whom they have been given no tracking details. ${ }^{21}$

The indiscriminate separation of parents and legal guardians from children accompanying them was stopped by public outcry. But, out of the glare of public

17 Hearing on Migrant Family Separation Policy before the House Committee on Energy and Commerce 6 Subcommittee on Oversight and Investigations, 116th Congress 3 (2019) (statement of Jack P. Shonkoff, M. D.).

18 Ms. L v. Immigration and Customs Enforcement, 310 F. Supp. 3d 1133, 1149-1150 (S.D. Cal. 2018).

19 For excellent accounts of US policy in respect of migrant children, see L. Briggs, Taking Children: A History of American Terror (Berkeley: University of California Press, 2020); P. G.

Schrag, Baby Jails: The Fight to End the Incarceration of Refugee Children in America (Berkeley: University of California Press, 2020).

20 Ms. L v. Immigration and Customs Enforcement.

${ }^{21}$ Personal communication to author from ACLU lead counsel. 
attention, family separation continues. ${ }^{22}$ The new version of the policy, so-called For Cause separation, has affected thousands of children, including very young ones. This policy involves separation of children from nonparent relatives - grandparents, older siblings, and other relatives. A few reported cases describe separations from supposedly "unsuitable" parents - in one case a father whose only disqualifying feature was a shoplifting conviction, in another, a parent who was HIV-positive. ${ }^{23}$ Once these children are separated from their relatives - allegedly to guard against abuse or the risk of trafficking - they are placed in facilities that have attracted strong criticism. A particularly searing indictment was offered by an experienced and widely respected Columbia Law School expert. In her testimony before the US House of Representatives Committee on Oversight and Reform, Elora Mukherjee included the following account:

In June 2019, a small team of lawyers, a doctor, and I met with nearly 70 immigrant children detained ... in Texas .... The children ... were dirty and distressed, held for days and weeks without access to soap, showers, toothbrushes, clean clothing, adequate nutrition, or adequate sleep. Over the past year, at least seven children are known to have died in federal immigration custody or shortly after being released. These tragedies occurred after nearly a decade of no reported child deaths. Every day, children are ripped apart from their family members at our borders and detained without access to their loved ones. These separations leave young children isolated for days, weeks and months without their parents, grandparents, aunts, siblings and other familial adult caregivers. ${ }^{24}$

The lawyer's testimony to Congress included searing quotations from some of the children interviewed. A typical excerpt: "I started taking care of [a five-year-old girl $\ldots$ after they separated her from her father. I did not know either of them before that. She was very upset. The workers did nothing to try to comfort her. I tried to comfort her and she has been with me ever since. [This five-year-old girl] sleeps on a mat with me on the concrete floor. We spend all day every day in that room. There are no activities, only crying" (age 15, female). ${ }^{25}$

The rollout of "zero humanity" immigration policies by the Trump administration continues. Indeed it is accelerating, building on the grim foundations laid very early on by this administration - the incoherent executive orders banning Muslims, ${ }^{26}$ the elimination of the Central American minors' program designed to

${ }^{22}$ S. Pierce, Immigration-Related Policy Changes in the First Two Years of the Trump Administration (Washington, DC: Migration Policy Institute, 2019), p. 2.

23 Personal communication from ACLU counsel to author at Harvard University conference on November 13, 2019.

24 Hearing on the Trump Administration's Child Separation Policy: Substantiated Allegations of Mistreatment before the House Committee on Oversight and Reform, 116th Congress (2019) (statement of Elora Mukherjee, Professor, Columbia Law School), p. 2.

25 Ibid., p. 9 .

26 "Protecting the Nation from Foreign Terrorist Entry into The United States," Executive Order 13769, March 6, 2017, www.whitehouse.gov/presidential-actions/executive-order-protecting- 
provide alternative routes to safety for children fleeing gang warfare and drug murders in the countries of the Northern Triangle, ${ }^{27}$ the withdrawal of temporary protected status in the United States for law-abiding and self-supporting survivors of calamities in Honduras, El Salvador, and Haiti. ${ }^{28}$

A central plank of the Trump administration's immigration control agenda moving forward is large-scale and prolonged child migrant imprisonment. The government's justification for this is twofold: a need to address unmanageable border arrivals and an intention to stop what it considers the perverse incentive, generated by the current child release policy, to transport children on dangerous journeys. Paradoxically, then, the government claims that by preventing children at serious risk of gang violence from accessing safety, it is protecting them from harm. But at the same time, post-pandemic border control policies have done exactly the opposite. They have forced children seeking asylum back across the border with no attention to their needs or vulnerabilities, they have subjected families awaiting processing of their asylum claims to indefinite delays as they await their turn in dangerous Mexican borderlands, and, despite court orders mandating release of child migrants from detention, they continue to hold significant numbers of children in crowded and unsanitary facilities.

So far, the Trump administration has been unable to implement child migrant detention on a comprehensive and "deterrent" scale because of Flores, the muchcited Supreme Court settlement that addresses child migration detention. ${ }^{29}$ Flores became a household name during the family-separation debacle. When Supreme Court cases become household names, it is reasonable to suggest that a watershed US political event has taken place. So it was with Dred Scott, Brown v. Board of Education, and Roe v. Wade. And so it is with Flores. The administration is currently attempting to reverse Flores to clear the way for indefinite detention of migrant children with their families.

The Flores case has been on the books for thirty-five years. It started off as a challenge to the indefinite detention of unaccompanied child migrants in harsh facilities where children were commingled with unrelated adults. It has continued as a platform for challenging the circumstances in which migrant children, both

nation-foreign-terrorist-entry-united-states-2/; "Raising the Global Travel Security Bar: DHS Announces New Travel Restrictions on Six Countries and Updated Process for Evaluating Foreign Country Compliance," Department of Homeland Security, January 31, 2020, www.dhs .gov/news/2020/o1/31/raising-global-travel-security-bar-dhs-announces-new-travel-restrictions-six.

27 "Status of the Central American Minors Program," United States State Department, Office of the Spokesperson, November 8, 2017, www.state.gov/status-of-the-central-american-minors-pro gram/.

${ }_{28}$ Continuation of Documentation for Beneficiaries of Temporary Protected Status Designations for El Salvador, Haiti, Honduras, Nepal, Nicaragua, and Sudan, 84 Fed. Reg. 59403 (November 4, 2019), www.federalregister.gov/documents/2019/11/04/2019-24047/continuationof-documentation-for-beneficiaries-of-temporary-protected-status-designations-for-el.

29 Reno v. Flores, 507 U.S. 292 (1993). 
unaccompanied and accompanied by their families, are denied their liberty in the absence of any criminal charges, but merely because of their immigration status.

Flores's complex and tortuous history spans the past three decades of violence in Central America, from the murderous civil wars of the 1980s to the pervasive gang criminality of the twenty-first century, violence in which the United States has continually been deeply implicated. In the 1980s, the United States was a key supporter of paramilitary activity shoring up the Central American dictatorships by providing them with military training, arms, and other forms of support. Many young adults targeted by military were forced to flee; Jenny Flores was one of thousands of children left behind in El Salvador, who traveled unaccompanied to reunify with a US-based parent. ${ }^{30}$

In the 1990s and through the twenty-first century, the United States has been the entity responsible for the export of gang violence from its metropolitan cities, a clear example of the spill-over effect of misguided and poorly considered punitive measures against young migrants. As discussed in more detail later, the violence has turned the so-called Northern Triangle countries of Central America, Guatemala, Honduras, and El Salvador into murder capitals of the world. The gang export process originated with the deportation from US cities, primarily Los Angeles, of sizeable numbers of convicted young Central American migrants, who had been brought to the United States as infants. These young immigrants, many living in impoverished neighborhoods and in families with parents working very long hours to make ends meet, had become ensnared in the drug and gang warfare in inner city Los Angeles. After serving their criminal sentences, they were ordered deported. By forcibly sending these long resident offenders to "homes" to which they had no ties, the United States was operating a discriminatory form of double jeopardy - piling on the draconian sanction of deportation after the young migrants had already served their criminal sentences. The United States was also creating what Dan Kanstroom memorably terms a new "American diaspora," a community of deracinated youth who found status and a means of survival through the launch of gang warfare in the impoverished environments to which they were forced back. ${ }^{31}$

A new chapter in the story of punitive and misguided policies targeting child migrants from Central America is now starting with the attack on Flores. The fascinating history of the Flores case, a decades-long battleground for the protracted fight over the length and conditions of child migrant confinement, is brilliantly recounted by Phil Schrag in his new book, Baby Jails. ${ }^{2}$ He highlights the contestation between constitutional principle (children's liberty interests), represented by activist immigrant rights advocates, and administrative discretion in the service of

30 Schrag, Baby Jails.

${ }^{31}$ D. Kanstroom, Aftermath: Deportation Law and the New American Diaspora (Oxford: Oxford University Press, 2012).

$3^{2}$ Schrag, Baby Jails. 
migrant exclusion, represented by government lawyers and their agents. As Schrag shows, government actors have attempted to keep publicity and legal representatives at arm's length from asylum seekers in desperate need of lawyers by siting migration detention facilities in remote locations. But immigrant rights advocates have vigorously countered, organizing round-the-clock schedules to ensure pro bono client representation and track detention conditions. The book describes government officials purposely moving child migrants to undisclosed new locations just before their hearings without informing appointed lawyers to undercut the possibility of legal representation. But it also recounts determined counter-moves, such as congressional interns surreptitiously videoing conditions in detention facilities to publicize them. The message is that defending non-citizens' basic rights to humane treatment requires much more than recitation of constitutional principle - extraordinary dedication and ingenuity have been the bedrock of moves to counter the administration's rollback of basic legal obligations.

As of this writing, the administration has applied for a court order to reverse the Flores settlement that governs the terms of child migrant detention. Flores prohibits the incarceration of migrant children for more than twenty days, irrespective of whether or not they are with their parents. It also requires that migrant children in state custody be held in certified facilities, specifically licensed to provide appropriate care. ${ }^{33}$ If the government is successful in reversing Flores, it will be able to indefinitely detain migrant children with their families. The fact that family detention space is being expanded to accommodate 20,000 children is ominous. It remains to be seen whether the courts and American public will tolerate this cruel policy shift any more than they did its predecessor, family separation.

\section{Externalizing Humanitarian Responsibility}

Apart from the contested litigation centered on the Flores settlement, the Trump administration is pursuing additional exclusion and deterrent strategies, all of which violate migrant children's rights to protection and safety, and all of them under legal challenge. The common denominator for these policies is externalization - a process by which the United States exploits its economic and political heft to dislodge its humanitarian obligations onto its much poorer and more unstable neighbors.

Ferocious violence in Central America shows no signs of abating. Homicide rates in the Central Triangle remain the highest in the world - 62 homicides per 100,000 people in El Salvador $\left(\#_{1}\right), 4^{2}$ per 100,000 in Honduras $\left(\#_{5}\right)$, and 26 per 100,000 in

33 For a detailed account of the Flores settlement and its changing provisions, see Schrag, Baby Jails. 
Guatemala $\left(\#_{1} 6\right){ }^{34}$ The region is particularly dangerous for women and children. According to the UNHCR, 82 percent of Central American women asylum seekers reported that they would face torture or persecution if returned to the region. ${ }^{35}$

In the face of life-threatening circumstances, migration deterrence simply does not work. Children and their families are continuing to flee and to seek protection in the United States. More than 76,o2o unaccompanied children and more than 473,000 adults and children traveling in family units were apprehended at the Unites States' southern border in 2019, the highest numbers ever recorded. ${ }^{36}$

Having failed with family separation, the administration has turned to other strategies. In 2018, then-Attorney General Jeff Sessions announced a proposal to radically curtail the scope of asylum by excluding from protection survivors of persecution by private actors, including murderous spouses and brutal gangs. ${ }^{37}$ The bar for gaining asylum in those cases was already high - applicants had to demonstrate that they could not get protection from their governments, that they could not secure safety by traveling to distant sites within their own countries, and that the harm they feared rose to the very high threshold of "persecution." So only a small proportion of the most extreme cases of domestic and gang-related violence were successful - no open door or "flood" of asylum grants had ever existed. But this new policy bars access completely. In so doing it signals a reversal of decades of American refugee practice.

The attack on asylum access has been further accelerated by three other momentous developments. The first is the June 26, 2018, majority Supreme Court judgment in Hawaii v. Trump that upheld the administration's ban on all access to the United States for nationals from several majority-Muslim countries. As Stephen Legomsky, a widely revered legal scholar, has noted, the Supreme Court has, time and again, "declared itself powerless to review even those immigration provisions that explicitly classify on such disfavored bases as race, gender, and legitimacy." ${ }^{8}$

American citizen children will no longer be able to be joined in their country by parents, grandparents, or siblings who are, for example, Iranian or Syrian. People fleeing the devastating (US-supported) conflict in Yemen that has left 12,000 civilians dead and spread famine and disease to millions will no longer be able to join their relatives long settled in the United States. Young people from the marked

34 "Intentional Homicides (per 100,000 people)," United Nations Office on Drugs and Crime, International Homicide Statistics, https://data.worldbank.org/indicator/VC.IHR.PSRC.P5?mo st_recent_value_desc=true.

35 "UNHCR Warns of 'Looming Refugee Crisis' in the Americas," UN High Commissioner for Refugees. October 28, 2015, www.unhcr.org/563ofc6ag.html.

36 "Southwest Border Migration FY 2019," U.S. Customs and Border Protection, November 14, 2019, www.cbp.gov/newsroom/stats/sw-border-migration/fy-2019.

37 Matter of AB-, 27 I\&N Dec. 316 (A.G. 2018), Interim Decision \#3929, www.justice.gov/eoir/ page/file/1070866/download.

$3^{8}$ S. H. Legomsky, "Immigration Law and the Principle of Plenary Congressional Power" (1984) 1984 Supreme Court Review 255-307 at 255. 
countries, however able, will be denied access to US universities, and patients seeking advanced medical care will have to turn elsewhere. Another, lessremarked-upon, consequence of the Supreme Court's judgment is its devastating impact on the LGBTI community. A significant minority of asylum applicants from the excluded countries have turned to the United States for safety in the face of barbarous anti-gay policies in their home countries - homosexuality is punishable by death in Iran, Syria, and Yemen. ${ }^{39}$ This door is now closed.

To further its externalization strategy, the administration has developed several other policies designed to block, deter, or return humanitarian migrants, policies that have a disproportionate impact on Central American children and their families. In January 2019, months after the family separation policy was halted, but with the same deterrent intent, the US government introduced the mis-named "Migration Protection Protocols" (MPP), more accurately known as the "Remain in Mexico Policy." ${ }^{\circ}$ For the first time, border officials are forcing child refugees and their families, who present themselves at the United States' southern border to apply for asylum, to return to Mexico. There, in a no-man's-land known to be riddled with drug traffickers and criminal cartels, certified as a "Do Not Travel" area by the US State Department, the asylum seekers have to spend months waiting for their hearings to be listed. US asylum officials, protesting the new policy, described it in a court petition they lodged: "Prior to the MPP, our country's processing of asylum applications ensured that people fleeing persecution would not be ... returned to a territory where they may face persecution or threat of torture." ${ }^{1}$ This externalization practice recalls the infamous Haitian maritime interdiction policies of the 1980s and 1990s. According to October 2019 estimates, more than 66,000 Central American humanitarian migrants have been affected, of whom approximately 5,000 are under five years old. ${ }^{42}$ According to firsthand reports, 50 percent of those returned report being kidnapped in Mexico; systematic sexual violence has also been reliably documented. ${ }^{43}$ These reports and other confirmed cases of shootings and ransoms have not, to date, forced a revision of US border practice.

39 “\#Outlawed: The Love That Dare Not Speak Its Name," Human Rights Watch, http://internap .hrw.org/features/features/lgbt_laws/.

40 "Migration Protection Protocols," Department of Homeland Security, January 24, 2019, www .dhs.gov/news/2019/o1/24/migrant-protection-protocols.

${ }^{41}$ Local 1924, Amici Brief 2, Innovation Law Lab v. McAleenan, No. 19-15716 (9th Cir. June 26, 2019).

42 'US Move Puts More Asylum Seekers at Risk: Expanded 'Remain in Mexico' Program Undermines Due Process," Human Rights Watch, September 25, 2019, www.hrw.org/news/ 2019/og/25/us-move-puts-more-asylum-seekers-risk\#; R. Mishor and K. Hampton, "The Worst Immigration Policy You've Never Heard of," The Hill, January 8, 2020, https://thehill.com/ opinion/immigration/477329-migrant-protection-protocols-the-worst-immigration-policy-youvenever.

43 "Delivered to Danger: Illegal Remain in Mexico Policy Imperils Asylum Seekers' Lives and Denies Due Process," Human Rights First, August 2019, www.humanrightsfirst.org/sites/ default/files/Delivered-to-Danger-August-2019\%20.pdf. 
At the same time as it is forcing vulnerable humanitarian migrants seeking protection back into Mexico, the US government is also severely rationing the rate at which US border officials accept asylum applications, a process referred to as "metering." This intentional rationing of an urgent humanitarian service exacerbates delay and fuels the sense of "crisis." Predictably, demand for asylum processing increasingly outstrips the ever more limited supply of officials charged with asylum processing responsibility.

Meanwhile, those asylum seekers who understandably try to circumvent this dramatic bottleneck by attempting to enter between official entry points and apply for asylum thereafter are subject to prosecution for illegal entry, the hard edge of the "zero tolerance" policy. In short, damned if you do, and damned if you don't. The well-established international norm protecting access to asylum irrespective of the manner of entry on the territory, clearly codified in the 1951 Refugee Convention, has been eliminated. It remains to be seen whether this frontal attack on established humanitarian law and principle will be upheld by the courts, but while it is in operation, it further undermines the access to protection for non-citizen children fleeing Central American violence.

It is not just Mexico's northern border that is affected. Under threat of crippling economic sanctions, the Trump administration has pressured Mexico to block refugee entry at its southern border by deploying, for the first time ever, its national guard forces. As of June 2019, Mexico had sent 15,000 untrained soldiers to police the border. In June 2019 alone, more than 30,000 Central Americans, including unaccompanied children, were detained in this way, which has led to overcrowding at 300 percent overcapacity in some Mexican detention centers. ${ }^{44}$ The Mexican government is now planning to close down these facilities, presumably by emulating US conduct and sending asylum seekers back across the border into Guatemala. ${ }^{45}$ Children fleeing gangs and other forms of violence now face much more costly and dangerous smuggling strategies to secure safety.

A third externalization measure is probably the most devastating to Central American children's chances of securing safety abroad. ${ }^{6}$ Adopting Europe's "safe third country" approach that forces asylum seekers to apply for protection in the first safe country they enter, even if they have family or other ties elsewhere, the Trump

${ }^{4}$ M. Meyer and A. Isacson, The "Wall" Before the Wall: Mexico's Crackdown on Migration at Its Southern Border (Washington, DC: WOLA, 2019), www.wola.org/analysis/mexico-southernborder-report/.

45 J. Valencia, "Mexico Closes 5 Immigrant Detention Centers," Arizona Public Media, March 7 , 2019, https://news.azpm.org/p/news-topical-border/2019/3/7/147445-mexico-closes-5-immigrantdetention-centers/.

$4^{6}$ Z. Kanno-Youngs, "Federal Judge Strikes Down Trump Administration's Asylum Rule," New York Times, July 1, 2020, www.nytimes.com/2020/07/o1/us/politics/trump-asylum-rulingimmigration.html. 
administration is proposing to completely block land entry via the southern border to all asylum seekers. If implemented, this would mean that only refugees rich enough to fly or organize visas for themselves would have the possibility of getting to the United States to seek asylum. In a macabre, Monty Pythonesque twist, the job of providing sanctuary to humanitarian migrants fleeing violence would then be left to the murder capitals of the world - Guatemala, El Salvador, and Honduras - all of whom have signed cooperative agreements to this effect with the United States. In addition, new proposals advanced by the Trump administration would gut the asylum process even further, compounding the impact of safe third country exclusion procedures with draconian restrictions to the substantive grounds required as proof of eligibility for refugee status. ${ }^{47}$

No European country, many of them addressing immigration pressures proportionately greater than the United States, has intentionally incarcerated migrant children or denied access to the asylum procedure to irregular entrants. Why? Not because they have unlimited reception capacity, not because they lack a deeply xenophobic element in their electorates, not because arguments about deterrence and moral blackmail as pragmatic migration control tools do not circulate. Countries do not incarcerate migrant children or eliminate the possibility of asylum for irregular entrants as a matter of fundamental moral and legal principle.

These policies and proposals highlight the growing outlier, even rogue status of the United States in the international sphere. American exceptionalism has long been acknowledged in relation to gun ownership, capital punishment, mass incarceration, and - in recent history - unapologetic use of torture. But this country's long history of celebrating its immigrant identity was a welcome aspect of US exceptionalism. Trump's infliction of harm on current populations of distress migrants eviscerates the best aspects of the American polity itself.

\section{Rights-Respecting and Feasible Alternatives}

It is worth considering the alternatives to these inhumane policies. International law, US constitutional obligations, and common humanity demand a radically different approach to children fleeing life-threatening violence. The fact that these children are non-citizens has no relevance to their claim for enforcement of rights legal rights, human rights, fundamental rights. Outrage at the family separation policy demonstrated that, across the political spectrum, the claim that the well-being of vulnerable children can legitimately be used as a deterrent to border crossing is untenable. Widespread global political consensus and international norms establish the opposition to child migrant detention and to punitive action against children

47 Z. Kanno-Youngs, “Asylum Officers Condemn What They Call ‘Draconian’ Plans by Trump,” New York Times, July 15, 2020, www.nytimes.com/2020/07/15/us/politics/asylum-officers-trump .html. 
charged with no criminal infractions. What is required, then, instead of punitive and deterrent policies?

There are much better alternatives. The first, and most crucial, involves a constructive and collaborative regional approach - not one that coerces neighbors to accept refugees destined for the United States (as the asylum cooperation agreements described earlier do), but one that deploys the United States' substantial resources - financial, political, and technical - to the urgent task of making the Northern Triangle countries safe again for children.

This is no easy task. The rule of law has been shattered by conflict, drug cartels, and the export of gang violence through deportations from the United States. Courageous local judges attempting to punish kleptocracy at the highest government levels have been forced to flee for their lives. These challenges are exacerbated by rural to urban migration caused by environmental damage. Children in overcrowded and under-resourced cities need safe and well-resourced schools, parents with jobs, effective health care, and playgrounds not threatened by gangs. Both selfinterest and the reparative obligations that result from decades of engagement with military regimes should drive substantial US investment in building these resources. Roberto Suro, a respected Central American expert, has pointed out that the Trump administration's total 2019 budget for the wall, immigration enforcement, and detention ( $\$ 44$ billion) is close to the combined GDP of El Salvador and Honduras ( $\$ 48$ billion). $4^{8}$ A portion of those huge sums deployed to encourage Northern Triangle economic development would greatly contribute to improved local conditions and attendant decreases in migration pressure. A civic intervention program introduced by the Obama administration in one of Honduras's most notorious neighborhoods produced excellent results. At an annual cost of \$100 million, an integrated set of schemes in Rivera Hernández, the most violent neighborhood in San Pedro Sula, the murder capital of the world for four years in a row, reduced the risk of crime and alcohol or drug abuse among targeted youth by 77 percent compared to their untargeted peers. The violence prevention program also increased conviction rates for those charged with homicide from a previous low of 4 percent to a record 50 percent. Most significantly, over the two-year period of intervention, the violence prevention program reduced by more than half the number of Honduran youth arriving at the US-Mexico border. ${ }^{49}$ This was one initiative in one neighborhood. Similar past initiatives in El Salvador have also been successful. Instead of canceling them, the administration should scale them up. This would improve youth safety and reduce migration pressures.

$4^{8}$ R. Suro, "We Need to Offer More Than Asylum," New York Times, July 14, 2018, www.nytimes .com/2018/o7/14/opinion/sunday/migration-asylum-trump.html.

49 S. Navarro, "Op-Ed: How to Secure the Border. Spoiler Alert: A Wall Won't Do It," Los Angeles Times, April 23, 2017, www.latimes.com/opinion/op-ed/la-oe-nazario-what-works-toend-illegal-immigration-20170423-story.html. 
Closer to home, at a fraction of the cost of prolonged incarceration, the administration could replace family detention pending a final immigration decision with supervised family release and a much speedier and better administered asylum process. As noted, previous efforts to do this have yielded excellent results. Recent data from the Department of Justice shows that 89 percent of all asylum applicants attended their final court hearing to receive a decision on their application, ${ }^{\circ}$ and among families and unaccompanied children who have access to legal representation, "compliance" with immigration court obligations is 98 percent. ${ }^{51}$ The United States could learn from its peers - other wealthy migration destination states addressing large-scale child migration - by providing legal representation and guardianship to unaccompanied children to ensure simpler and speedier court proceedings and more rational and just living arrangements. Guardians could ensure that children are accommodated in safety, with families or in childcare facilities, while they await decisions in their cases, and that they have access to appropriate educational and health facilities. Legal representatives could sift meritorious from unmeritorious cases, obviating the need for lengthy and costly court adjournments, negotiating safe returns home where this is in the best interests of the child, and ensuring prompt resolution by other means as appropriate, to the benefit of all parties. No one benefits from the uncertainty, cost, and misery generated by prolonged limbos.

Most critically, the United States should accept that, until it is abated by vigorous and effective development investments, the current humanitarian disaster facing children from the Central Triangle countries warrants special immigration policies. Instead of trumpeting the myth that physical or institutional barriers will prevent atrisk children from fleeing, the United States should institute deliberate and regulated policies to facilitate orderly child entry.

Many of the unaccompanied children who seek humanitarian entry in the United States have well-founded fears of persecution - they should qualify for refugee status. But the recent executive changes to US policy described earlier have restricted their chances, excluding those threatened by gang violence, for example, from qualifying for asylum.

For Central American children fleeing violence who have documented relatives in the United States, there should be refugee processing by US consulates in Central America. This would ensure safe travel, removing children from harm at home and en route. A program to do this that worked successfully was cancelled by the Trump administration..$^{2}$ It should be reinstated.

\footnotetext{
50 "Workload and Adjudication Statistics," United States Department of Justice, February 3, 2020, www.justice.gov/eoir/workload-and-adjudication-statistics.

51 "Priority Immigration Court Cases: Women with Children," TRAC Immigration, Syracuse University, https://trac.syr.edu/phptools/immigration/mwc/.

52 Pierce, Immigration-Related Policy Changes, p. 17.
} 
In addition, the United States could follow historical precedents - the Kindertransport for Jewish children fleeing the Nazis, the Pedro Pan movement for Cuban children fleeing Castro - and institute refugee resettlement programs, establishing reasonable annual quotas and a transparent, fair, and efficient system of admission for the most vulnerable Central American children. The Office of Refugee Resettlement could work with local US communities, tapping into the extensive bedrock of civic capacity and willingness to accommodate, support, mentor, and nurture refugee children. Canada's civic sponsorship program and Germany's remarkable network of engaged communities and municipalities provide excellent precedents.

Finally, the United States could deploy its unrivalled educational resources to encourage subsidized scholarship programs for at-risk children and adolescents. Many immigrant and children's rights advocates in schools and colleges would enthusiastically support such an initiative - the much celebrated Erasmus program in Europe, which has facilitated mobility for adolescents from Romania, Bulgaria, and Hungary to educational institutions in Germany, the United Kingdom, and Sweden, provides a powerful precedent. ${ }^{53}$ Nothing but benefit for US educational institutions and their students, the broader community, and of course the at-risk Central American children and youth could flow from such initiatives.

As in other complex social fields, what is needed to address the challenges generated by contemporary distress migration (a constant in human history) is clarity and equity. Clarity about who is eligible for protection, for work authorization, for family reunification, for receipt of a visa; equity in relation to the right to mobility, access to timely and fair procedures and legal representation, and protection of basic human rights.

Our societies have extensive unmet needs for manual and low-skilled labor, needs that are not matched by proportionate work visas - as a result, millions are employed in an irregular immigration status, a clear inequity. ${ }^{54}$ Our societies have extensive availability of educational opportunity given declining domestic fertility rates - yet only very wealthy non-citizen adolescents and young people (unless they are highly talented "scholarship" material) can access this opportunity, a clear inequity. Our societies are built on the founding notion that families are a fundamental social unit, the best context for child rearing - yet millions of children are separated from loving families for immigration reasons, a clear inequity. Our societies uphold the right not

\footnotetext{
53 "The 3oth Anniversary and You," European Commission, https://ec.europa.eu/programmes/ erasmus-plus/anniversary/3oth-anniversary-and-you-_en.

54 M. Sumption and D. G. Papademetriou, Legal Immigration Policies for Low Skilled Foreign Workers (Washington, DC: Migration Policy Institute, 2013), www.migrationpolicy.org/rese arch/legal-immigration-policies-low-skilled-foreign-workers; "Highly Skilled Migrants Are No Longer Welcome in America. Maybe," The Economist, June 23, 2020, www.economist.com/ united-states/2020/06/23/highly-skilled-migrants-are-no-longer-welcome-in-america-maybe.
} 
to be forced back home if there is a threat to life or freedom - yet millions are denied the opportunity to exercise that right, a clear inequity.

The proliferation of conflicts, the increase in environmental harms associated with climate change, the growing and increasingly evident social inequity across regions, and demographic transformations are complex factors that all impinge on migration and which must be addressed as part of the answer to unregulated and life-threatening movements of people. Migration cannot be fixed by migration strategies alone. There are no quick fix solutions, as the Trump administration has learnt to its cost.

In response to the large-scale flows of desperate distress migrants from Syria and other parts of the Middle East, Asia, and Africa into Europe in 2014 and 2015, the member states of the United Nations embarked on a systematic process to review global migration and refugee flows. In the fall of 2018, they signed two "global compacts," one on refugees and one on migrants. ${ }^{55}$ The compacts address many of the complexities bedeviling current migration policy - the lack of responsibility sharing for refugees, the dearth of legal and safe access to migration for many deserving and able populations, the imperative of linking migration and refugee policies with development strategies, and the urgency of attending to the human rights and needs of child migrants, whether accompanied by their families or unaccompanied. A central goal was to create integrated, global strategies for managing migration, sharing responsibility, and more adequately responding to the needs of the many constituencies implicated in contemporary migration.

Two years down the line from the initial, vigorous engagement with the global compacts' project, it is not clear that demonstrable progress has been achieved. The notion that migration management should be linked to development goals - and in particular to Sustainable Development Goal 10.7 that calls on state parties to "[f]acilitate orderly, safe, regular and responsible migration and mobility of people, including through the implementation of planned and well-managed migration policies" - is a powerful one. ${ }^{56}$ It sets a useful framework for action and for policy development. Several of the alternative policy approaches outlined here are consistent with this development approach. However, opinions differ when it comes to evaluating progress. Although some analysts are disappointed, critical of the fact that little political will has been galvanized and few if any significant improvements in

55 United Nations, Global Compact for Safe, Orderly, and Regular Migration, July 13, 2018, https://refugeesmigrants.un.org/sites/default/files/180713_agreed_outcome_global_compact_. for_migration.pdf; United Nations General Assembly, Report of the United Nations High Commissioner for Refugees: Part II. Global Compact on Refugees, U.N. Doc. A/73/12 (Part II) (September 13, 2018), www.unhcr.org/gcr/GCR_English.pdf.

${ }_{56}$ United Nations General Assembly, Transforming Our World: The 2030 Agenda for Sustainable Development, U.N. Doc. A/RES/70/1 (October 21, 2015), available at: www.refworld.org/docid/ 57b6eze44.html; "SDG 10: Reduce Inequality Within and Among Countries," United Nations Office on Drugs and Crime, www.unodc.org/unodc/en/about-unodc/sustainable-developmentgoals/sdg10_-reduce-inequalities.html. 
migration safety or humanitarian protection and resettlement have been secured, others suggest the opposite - that given the unrealistic nature of the global compact recommendations to start with, there are grounds for cautious optimism about incremental steps toward progress in both refugee integration and life-saving migration management.

The US government has signed on to the Global Compact on Refugees, though its annual rate of acceptance of resettled refugees is at an all-time low. The US government has withdrawn from the Global Compact on Migration, however, reflecting the isolationism of its current foreign policy and the failing commitment to sustainably improving the migration management system. Both these developments - the low resettlement rates and the failure to engage with constructive approaches to improved migration management - bode ill for the thousands of vulnerable Central American children and young people seeking safety from violence and the opportunity to lead productive and rewarding lives. They will create more business for people smugglers, higher casualties of fleeing children en route, and a greater burden of distress and trauma for thousands as they move from childhood to adulthood. But they will also strengthen the determination of child migrants and their supporters to press for alternatives, and to use all the means at their disposal to secure the rights and interests to which they are entitled. 